\title{
EXPERIMENTAL STUDY ON SEDIMENTATION REMOVAL OF PERVIOUS CONCRETE
}

\begin{abstract}
M. RAMA ${ }^{1}$, V. M. SHANTHI
Pervious concrete is a unique and effective material used to tackle important environmental problems, to maintain green, sustainable growth, and to reduce storm water runoff and pollutants. Clogging of pervious concrete is an important potential issue in serviceability, considered one of the primary limitations of pervious concrete systems. The sediment deposition pattern of pervious concrete was determined using three clogging materials: clay, sand, and clayey silty sand. The clogged specimens were cleaned by pressure washing, vacuuming, and a combined method. In total, ten clogging and cleaning cycles were carried out on each sample to evaluate the draining capacity of the pervious concrete. The clogging test was assessed by measuring the infiltration rate during clogging and after cleaning, for each cycle. The experiment results showed that a reduction in permeability due to different types of sedimentation material as well as recovery in permeability was achieved after applying various cleaning methods.
\end{abstract}

Keywords: Pervious concrete, clogging, permeability, sedimentation, storm water

\section{INTRODUCTION}

Pervious concrete is an environmentally friendly paving material used for carrying light traffic loads in urban areas as it acts as a sustainable material. Urbanization creates numerous problems such as erosion, flash floods, pollution of rivers, and a heat island effect. Nowadays, pervious concrete can be used for multipurpose applications to mitigate the above-mentioned problems. It can drain the surface runoff and controls the pollution from runoff water, reduces traffic noise,

\footnotetext{
${ }^{1}$ Assistant Professor., M.E., Government College of Technology, Department of Civil Engineering, Coimbatore - 641 013, Tamilnadu, India, e-mail: mrama@gct.ac.in

${ }^{2}$ Professor., Ph.D., Government College of Engineering, Department of Civil Engineering, Srirangam - 620012 ,

Tamilnadu, India, e-mail: dr.vmshanthi@gmail.com
} 
recharges aquifers, improves skid resistance, and minimizes the heat island effect in urban areas [14]. It is most widely used for vehicular access pathways such as residential driveways, service driveways, and roadway shoulders [5]. Pervious concrete is similar to conventional concrete, except for the addition of a fine aggregate which forms interconnected voids which allow water to pass through the concrete matrix. The voids of $15 \%$ to $35 \%$ of the total volume of pervious concrete are maintained by gap graded coarse aggregates and viscous cement which prevents the separation of the paste and aggregate [6]. The hydraulic performance of pervious concrete on draining storm water is dependent on the rate of sediment deposition with respect to time period analyzed. The main sources of clogging are suspended particles from surface runoff water, organic and inorganic particles from traffic activities, and localized vegetation or dust blown on the roadway [7-9]. Clay, sand, and clayey silty sand clogging can occur near agricultural fields, coastal areas, terrain areas, shoulders, and pavement surfaces.

The term "clogging" refers to a decrease in the permeability of a porous medium due to some physical, chemical, or biological process $[10,11]$. Around $70 \%$ of clogging was caused by suspended solids present in the sedimentation materials, $15 \%$ by microbial growth, $10 \%$ was caused by chemical reactions, and the remaining $5 \%$ by other means. Pervious concrete is prone to clogging by urban storm water runoff with a high concentration of suspended particles such as dirt, fine sand, and debris [12-14]. Dirt and debris can be removed when vehicles enter onto the surface made of pervious concrete. Previous pervious concrete studies have suggested that retention of coarse-sized materials does not have a significant clogging effect $[15,16]$. Most of the existing clogging studies have revealed research results based on infiltration tests or on destructive methods to identify the characteristics of clogging [17-24]. The clogging study of pervious concrete is limited, because the non-destructive experimental methods were not available for characterizing clogging. The Computed Tomography (CT) imaging method was used for non-destructive evaluation of clogging along the entire depth of the specimen [25].

This present study focuses on the investigation of the hydraulic performance of pervious concrete systems by inducing clogging using different sedimentation materials and evaluating its infiltration capacities. The experimental work was carried out to understand the efficacy of renovation methods in restoring the hydraulic performance of pervious concrete. 


\section{OBJECTIVE}

The clogging effect of pervious concrete based on three sedimentation materials, three different aggregate gradation, and three rehabilitation methods was tested. The reduction in permeability after clogging and the residual permeability after cleanup were determined.

\section{MATERIALS, MIX PROPORTIONS, AND SPECIMEN PREPARATION}

The pervious concrete mixtures were prepared using ordinary Portland cement and locally available granite as a coarse aggregate. The locally available aggregates were taken when passing through a $9.5 \mathrm{~mm}$ and remaining on a $4.75 \mathrm{~mm}$ sieve (S1), when passing through a $12.5 \mathrm{~mm}$ and remaining on a $9.5 \mathrm{~mm}$ sieve (S2), and when passing through a $16 \mathrm{~mm}$ and remaining on a $12.5 \mathrm{~mm}$ sieve (S3). The aggregate sizes were selected in order to facilitate gap grading and to maintain an open pore structure. The mixtures were proportioned using the above-mentioned aggregates with a water-tocement ratio of 0.33 [26] and an aggregate-to-cement ratio of 4 (for all mixtures). Water with a pH value of no less than 6 and conforming to the requirements of IS 456-2000 was used for mixing the concrete and curing the specimens. The fundamental properties of the cement, coarse aggregate, and water were tested and incorporated into the mix design of pervious concrete as per ACI 522R-2006 [27]. The mix was prepared using a laboratory mixer and cast in cylindrical mould measuring $100 \mathrm{~mm}$ in diameter with a height of $200 \mathrm{~mm}$. The pervious concrete specimens used in the tests were prepared based on ASTM C192 "Standard Practice for Making and Curing Concrete Test Specimens in the Laboratory" [28] as shown in Figure 1. The specimens were filled in cylindrical moulds in three layers and 25 blows were applied to each layer to achieve the required compaction. Twenty seven samples were cast for each type of aggregate gradation mix and cured in water for clogg test. Nine samples were used for testing sedimentation effect using three clogging materials, and the remaining 18 samples were used to test sand and clayey silty sand sedimentation followed by three cleaning methods. The results shown are the average of three samples in each test. 




Figure 1. Pervious concrete specimens

\section{EXPERIMENTAL INVESTIGATION}

\subsection{SEDIMENTATION MATERIALS}

Three types of clogging materials (clay, sand, clay silt sand) were used in this study, as shown in Figure 2. Particle size analysis was carried out for the sedimentation materials to influence the significant effect on infiltration. Sand, as a coarse sediment material, passing through a $2 \mathrm{~mm}$ sieve and retained on a 75 micron sieve, fine sediments passing through a 75 micron sieve containing $25 \%$ clay, and a clay silt sand combination of $60 \%$ coarse sediment and $40 \%$ fine sediment were taken for the clogging study. Clay, sand, and a combination of clayey silty sand were mixed with three litres of water at $40 \mathrm{~g}$ each, and then allowed to clog three different mixes of pervious concrete specimens [29].

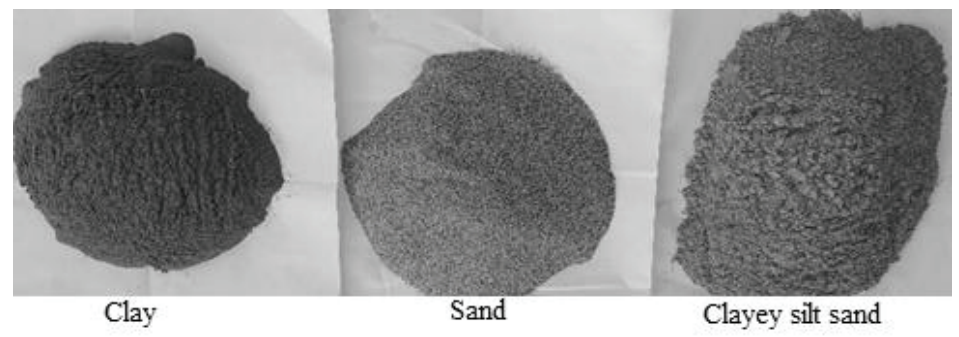

Figure 2. Sedimentation material 


\subsection{Clogging test}

Clogging can be assessed by measuring the permeability of the cylindrical specimens based on the falling head permeameter principle in a one-dimensional flow approach [30]. The apparatus consists of three different parts of a PVC pipe:- the first part is a long pipe $10 \mathrm{~cm}$ in diameter, fabricated with marked transparent covering over the required portion which had been connected to the second part, a sample-holder pipe also $10 \mathrm{~cm}$ in diameter with a height of $20 \mathrm{~cm}$, so that measurements of the water level could be obtained over period of a time. The third part is another pipe $10 \mathrm{~cm}$ in diameter connected with a reducer pipe and a flow control valve which is attached to the bottom of the sample-holder pipe, as shown in Figure 3. The pervious concrete specimens were covered on the sides in order to avoid the flow of water along the side surfaces in order maintain one-dimensional flow. The joints between the different parts of the setup were sealed to avoid leakage during testing. The overall setup was tied to a vertical post to maintain a vertical position at all times. Water was allowed to flow through the specimen by opening the valve, and the time required for the water to flow for a particular head from $h_{1}$ to $h_{2}$ was recorded. The coefficient of permeability was calculated using Darcy's law.

$$
k=\frac{A_{1} L}{A_{2} t} \ln \left(\frac{h_{2}}{h_{1}}\right)
$$

where, $\mathrm{A}_{1}$ - Area of the cross section of pipe in $\mathrm{cm}^{2}, \mathrm{~A}_{2}$ - Area of the cross section of sample in $\mathrm{cm}^{2}, \mathrm{~L}-$ Length of specimen in $\mathrm{cm}, \mathrm{t}$ - Time required for water flow from $\mathrm{h}_{1}$ to $\mathrm{h}_{2}$ in Sec., $\mathrm{h}_{1}$ - Initial head in $\mathrm{cm}, \mathrm{h}_{2}-$ Final head in $\mathrm{cm}$.

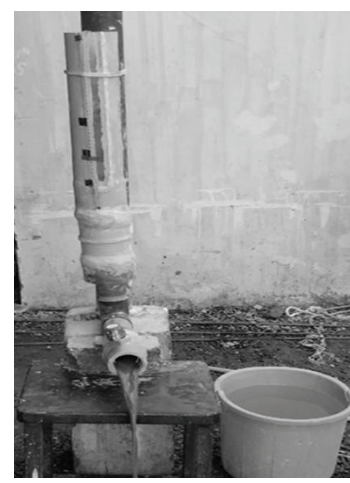

Figure 3. Clogging test

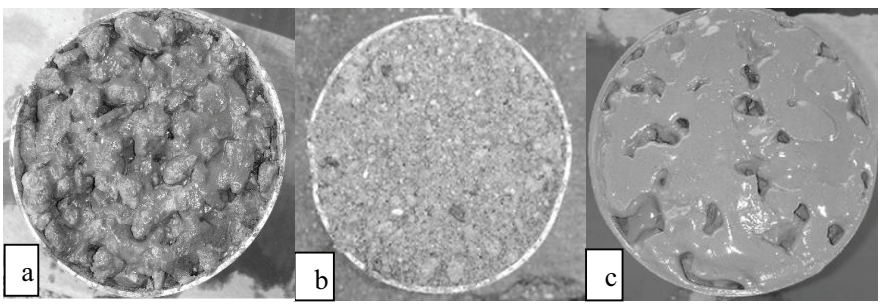

Figure 4. Clogged specimen a) Clay, b) Sand,c) Clayey silt sand 
A Clogging cycle consists of both clogging in the first step and cleanup in the second step. In each cycle of the test, the clogging material is mixed evenly with water and poured on the top of the tested specimen, and then permeability is measured by allowing water to flow through the specimen along with the suspended clogging material. The water is completely drained out and one of the treatment methods is selected to clean the clogged specimen, as shown in Figure 4. After cleaning, the permeability test was conducted again by allowing pure water to flow through the cleaned specimen, and permeability was again recorded. Specimens were subjected to ten repeated clogging cycles, including both clogging and the cleanup procedure. Time was recorded for a particular interval of water flow, and permeability was measured for each clogging and cleaup.

\subsection{Maintenance Method}

\subsubsection{Pressure washing}

Pressure washing was applied directly to the surface of the specimen by a power head cone nozzle which is used to concentrate water in a narrow cone, as shown in Figure 5. The nozzle creates weak bonds between clogged particles and concrete, so that the clogging particles move inside the pore, reach the bottom surface, and rest on the underlying soil or gravel reservoir. Pressure washing of clogged pervious concrete pavement retains $80 \%$ to $90 \%$ of the permeability [31]. The pressure washing method can be recommended for high-sedimentation areas after scrubbing to remove leftover dirt.

\subsubsection{VACUUM WASHING}

Vacuuming units contain a blower system which produces a high-velocity air column, which exerts forced air against the pervious concrete specimen, as shown in Figure 6. The high-volume air blast loosens the debris from the surface of the specimen, then transports it across the width of the sweeping head, and lifts it into the containment hopper through a suction tube. Thus, clogged materials and debris are loosened from the pavement and sucked into the cleaning unit. Vacuum units may be the most effective method of cleaning smaller installations, such as sidewalks, plazas, or small parking lots [32]. 

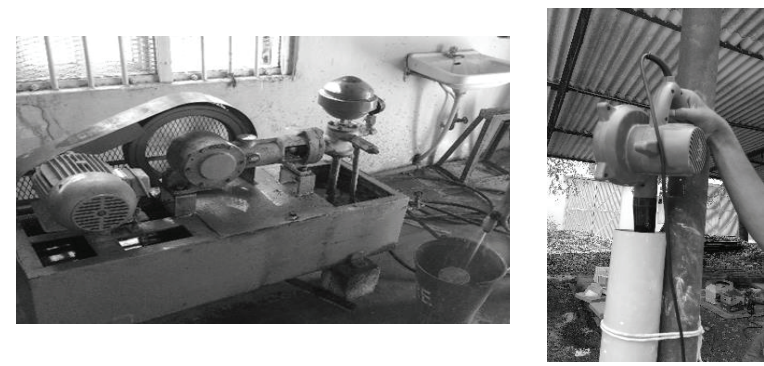

Figure 5. Pressure washing test

Figure 6. Vacuuming test

\subsubsection{COMBINED METHOD}

The particles deposited on the pervious concrete surfaces are sucked out and make the surface and interconnected pores open using both pressure washing and vacuuming. Recent studies represent the efficacy of washing porous pavements with clean, low-pressure water, followed by immediate vacuuming [33]. If the pervious concrete surface tends to clog in such a mannar where routine vacuum sweeping may not restore infiltration rate continuouesely, a more intensive level of treatment may be required. Vacuuming followed by pressure washing shows best method of cleaning and shows improved efficiency in the recovery of the infiltration rate. This combined clogcleaning method of pressure washing and vacuuming has proved effective in cleaning different sediments.

\section{RESULTS AND DISCUSSION}

\subsection{EFFECTS OF SEDIMENTATION MATERIALS}

This experimental study on the hydraulic performance of pervious concrete using three different sedimentation materials was carried out in order to understand its long-term effects. A significant reduction in permeability due to clogging leads to proper maintenance performed at regular intervals. The percentage of permeability decreased due to clay clogging materials for various mixes by $7 \%, 8 \%$, and $8 \%$ respectively, for the $\mathrm{S} 1$ aggregate, $\mathrm{S} 2$ aggregate and $\mathrm{S} 3$ aggregate mixes (as shown in Figure 7a). It was observed that clay clogging causes much less reduction in permeability after ten cycles of clogging, hence no requirement for any cleaning methods. In this 
test, more than $92 \%$ initial permeability was retained after 10 cycles of sedimentation loading. The reduction in permeability is due to the very fine particles which stick within the pores, and other particles transported through water.

When sand was used as the sedimentation material, a significant reduction in permeability was measured in all the three mixes, as shown in Figure $7 \mathrm{~b}$. The initial permeability is $0.40 \mathrm{~cm} / \mathrm{s}, 1.10$ $\mathrm{cm} / \mathrm{s}$, and $1.75 \mathrm{~cm} / \mathrm{s}$, respectively, for the $\mathrm{S} 1, \mathrm{~S} 2$, and $\mathrm{S} 3$ aggregate mixes. The $\mathrm{S} 3$ aggregate mix exhibits higher initial permeability and higher residual permeability after 10 cycles of clogging. The percentage of reduction in permeability is $72 \%, 54 \%$, and $30 \%$, respectively, for the S1, S2, and S3. The smaller size (S1) aggregate mix represents the lowest (28\%) percentage of retention of initial permeability from among the three mixes. Residual permeability changes directly with respect to size of aggregate and porosity of the specimen. An average of more than $50 \%$ permeability from all three mixes was lost for sand sedimentation, where most of the sand particles were retained either on the surface or within the pores of the specimen. In this sedimentation test, pervious concrete specimens with low porosity act as a filter layer to remove greater size solid particle in the sedimentation load and induces reduction in permeability. The effect of sedimentation and reduction in permeability of pervious concrete was influenced by porosity and type of clogging material.

When clayey silty sand was used as a sedimentation material similar to sand, a significant change in permeability occurs for all the three mixes, as shown in Figure 7c. The initial permeability is $0.44 \mathrm{~cm} / \mathrm{s}, 1.21 \mathrm{~cm} / \mathrm{s}$, and $1.84 \mathrm{~cm} / \mathrm{s}$, respectively, for the $\mathrm{S} 1, \mathrm{~S} 2$, and $\mathrm{S} 3$ aggregate mixes. The percentage of reduction in permeability is $52 \%, 44 \%$, and $36 \%$, respectively, for the S1, S2, and S3 mixes due to clayey silty sand sedimentation. It was found that clay particles were flushed though the flowing water and sand particles were retained on the top surface of the specimen. In clayey silty sand sedimentation, a blended material with a wide range of distribution of particle size causes clogging of pores. The specimens with greater sizes of aggregate show a high pore volume which leads to an increase in sedimentation load-carrying capacity, hence the percentage of initial permeability remaining increases. 


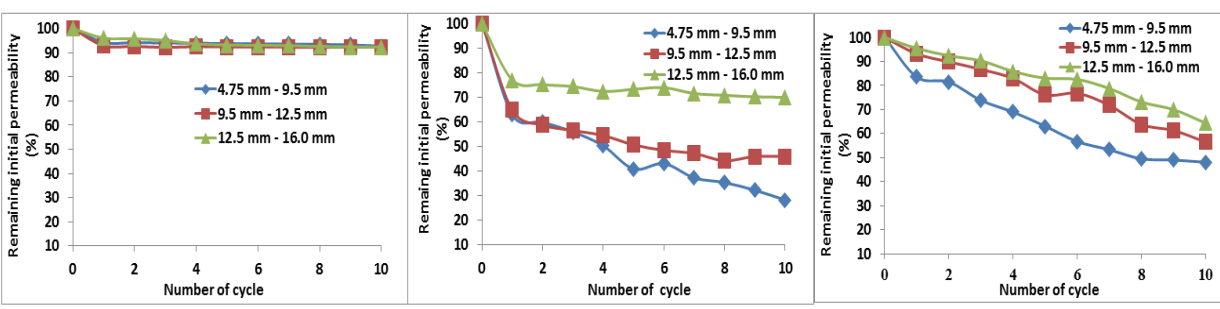

Figure 7. a) Clay sedimentation b) Sand sedimentation and c) Clayey silty sand sedimentation

\subsection{EFFECT OF CLEANING METHODS}

According to the clogging test, the selection of cleaning method depends on the porosity of the pervious concrete and characteristics of its sedimentation materials. Pressure washing and vacuuming show approximately the same cleaning performance outcome, and a combined method shows a slightly higher percentage of remaining initial permeability after 10 cycles of sand clogging and cleaning as shown in Figure 8. The recovery of permeability at the end of each clogging cycle by pressure washing and vacuuming in sand sedimentation cleaning is $78 \%, 79 \%$, and $81 \%$ for the $\mathrm{S} 1, \mathrm{~S} 2$, and S3 mixes, respectively, which is consistent for the S1 and S2 mixes, but slightly increased for the S3 mix due to increased porosity. A drop in permeability after the $6^{\text {th }}$ cycle is consistent for all three mixes due to the continuous filling of sediments into pores, and the depth of sediment deposition increases with respect to the clogging cycle. The improvement in permeability achieved by the combined method is $81 \%, 83 \%$, and $85 \%$ for the $\mathrm{S} 1, \mathrm{~S} 2$, and $\mathrm{S} 3$ mixes, respectively. Large-sized sedimentation particles deposited at the top surface in sand clogging can be effectively removed by pressure washing, and the lowest amount of sediments was collected at the bottom surface of the specimen. The fine sedimentation particles deposited inside the pores can be cleaned by the vacuuming method. It was confirmed that the combined method exhibits better

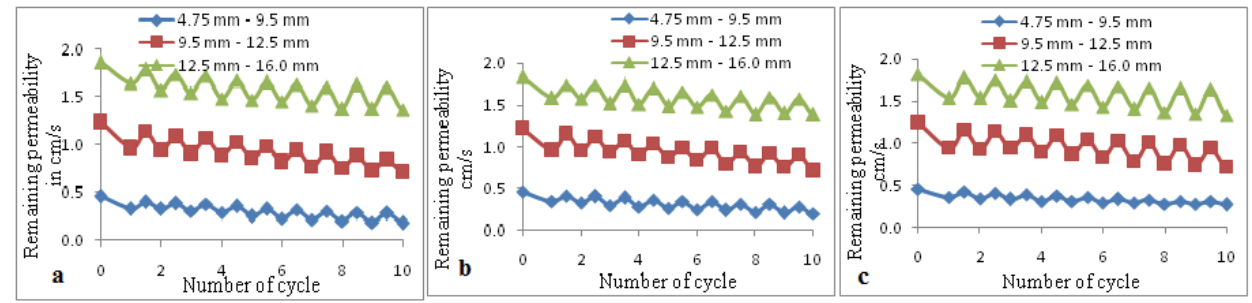

cleaning efficiency than pressure washing and vacuuming individually for all three mixes. 
Figure 8. Sand clog cleaning by a) Pressure washing b) Vacuuming and c) Combined method The permeability of the clayey silty sand sedimentation load can be recovered by pressure washing, vacuuming, and a combination of the two methods, as shown in Figure 9. In the pressure washing method, the recovery of permeability at the last stage of the clogging cycle is $69 \%, 75 \%$, and $79 \%$ for the three types of mixes which significantly differ from each other. The recovered permeability using the vacuuming method is $73 \%, 74 \%$, and $77 \%$ and with the combined method $77 \%, 81 \%$, and $83 \%$ for S1, S2, and S3 respectively. The blended particle size distribution of sedimentation materials causes a high intensity of deposition in pores, occurring faster than sand sedimentation. Clogging due to fine particles such as clay or silt that are easily trapped within the pores of pervious concrete at a certain depth is difficult to clean. The trapped cohesive particles inside pores can be effectively removed by vacuuming. The cleaning efficiency in clayey silty sand sedimentation was improved by the combined method of vacuuming and pressure washing.

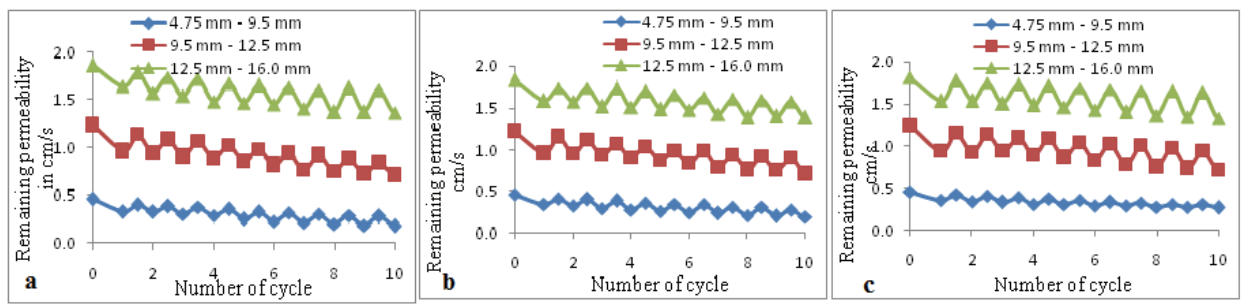

Figure 9. Clayey silty sand clog cleaning by a) Pressure washing b) Vacuuming c) Combined method

\section{CONCLUSION}

In this experimental investigation, pervious concrete specimens were exposed to 10 cycles of sedimentation loading in order to predict changes in their infiltration rate. Three types of sediments were used to create realistic clogging conditions and three sedimentation removal methods were employed to compare the cleaning efficiency of each method. Three different sizes of coarse aggregates were selected to incorporate into the pervious concrete mix.

Large-sized pores in pervious concrete allow the sediments to pass along with water, and small pores restrict the entry of large-sized sediments through the top surface of the pervious concrete. 
The initial permeability is high for the bigger size of aggregate mix which results in high intensity of residual velocity at end clogging. The drop in permeability and the recovery in permeability after cleaning are inversely related to each other.

It was identified that fine-sized cohesive sedimentation materials cause a minimum reduction in permeability, whereas coarse-sized non-cohesive materials cause a significant reduction in permeability after clogging.

The pressure washing and vacuuming methods reveal consistent performance in the cleaning of sand sedimentation, whereas it significantly differs in the cleaning of clayey silty sand sedimentation. Based on experimental test results, this combined cleaning method is considered as the best permeability recovery method for both sand and clayey silty sand sedimentation.

The results of this study indicate that sedimentation cleaning methods can considerably restore the performance of pervious concrete pavements for better storm water management.

\section{REFERENCES}

1. Tennis, D Paul, L. M. Leming, "Pervious concrete pavements", PCA Serial No. 2828. Skokie, IL: Portland Cement Association, 2004.

2. Yang, Jing, G. Jiang."Experimental study on properties of pervious concrete pavement materials" , Cement and Concrete Research 33.3: 381-386, 2003.

3. J.Sansalone, X. Kuang, "Permeable pavement as a hydraulic and filtration interface for urban drainage", Journal of Irrigation and Drainage Engineering 134.5: 666-674, 2008.

4. B. Huang, J.Cao. "Laboratory and Analytical Study of Permeability and Strength Properties of Pervious Concrete", The University of Tennessee, Knoxville, 2007.

5. Scholz, M \& Grabowiecki, P, 2007, 'Review of permeable pavement systems', Building and Environment, vol. 42, no. 11, pp. 3830-3836.

6. L. M. Haselbach, S Valavala, "Permeability predictions for sand-clogged Portland cement pervious concrete pavement systems." Journal of environmental management 81.1: 42-49, 2006.

7. C. B. Nielsen, "Clogging of Porous Pavements", The Cleaning Experiment. Road Directorate, Danish Road Institute, 2007.

8. N. R. Siriwardene, A. Deletic, "Clogging of stormwater gravel infiltration systems and filters: Insights from a laboratory study", Water research 41.7: 1433-1440, 2007.

9. C. F. Yong, A. Deletic, "The clogging behavior and treatment efficiency of a range of porous pavements", $11^{\text {th }}$ International Conference on Urban Drainage, Edinburgh, Scotland, UK 2008.

10. P. P. Alfredo, "Integrated modeling of clogging processes in artificial groundwater recharge", Technical University of Catalonia, Spain, 2000.

11. H. Bouwer, "Artificial recharge of groundwater: hydrogeology and engineering", Hydrogeology Journal, 10.1: 121-142, 2002.

12. A.Caselles-Osorio, et al. "Solids accumulation in six full-scale subsurface flow constructed wetlands", Water Research 41.6: 1388-1398, 2007.

13. O. Deo, M. Sumanasooriya, "Permeability reduction in pervious concretes due to clogging: experiments and modeling", Journal of Materials in Civil Engineering 22.7: 741-751, 2010.

14. G. F. Hua, et al., "Clogging pattern in vertical-flow constructed wetlands: Insight from a laboratory study", Journal of Hazardous Materials 180.1: 668-674, 2010. 
15. N. González-Angullo, et al., "Runoff infiltration to permeable paving in clogged conditions", Urban Water Journal, 5.2: 117-124, 2008.

16. L. Haselbach, et al., "Pervious concrete testing methods." Low Impact Development Redefining Water in the City: 180-192, 2010.

17. Ongel, J. Harvey, "Assessment of clogging in open graded mixes in California", International ISAP Symposium on Asphalt Pavements and Environment. Zurich, Switzerland. $18^{\text {th }}-20^{\text {th }}, 2008$.

18. S. A. Tan, T. F. Fwa, "Clogging Evaluation of Permeable Bases" Journal of Transportation Engineering, 129.3: 309-315, 2003.

19. S. D. Pezzaniti, C. Beecham, "Influence of clogging on the effective life of permeable pavements", Water Management, 2009.

20. J .P. Coughlin, C. D. Chelsea, "Infiltration and clogging by sand and clay in a pervious concrete pavement system", Journal of Hydrologic Engineering 17.1: 68-73, 2011.

21. M. Dougherty, M Hein, "Quick surface infiltration test to assess maintenance needs on small pervious concrete sites." Journal of Irrigation and Drainage Engineering 137.8: 553-563, 2010.

22. C. Brown, A. Chu, "Characteristics of sediment removal in two types of permeable pavement", water Qual. Res. J. Can, 44.1: 59-70, 2009.

23. M. E. Vancura, K. MacDonald, "Location and depth of pervious concrete clogging material before and after void maintenance with common municipal utility vehicles.", Journal of Transportation Engineering 138.3: 332 338,2012 .

24. J. Sansalone, X. Kuang, "Filtration and clogging of permeable pavement loaded by urban drainage", Water research 46.20: 6763-6774, 2012.

25. K. N. Manahiloh, B. Muhunthan, "X-ray computed tomography and nondestructive evaluation of clogging in porous concrete field samples." Journal of Materials in Civil Engineering 24.8: 1103-1109, 2012.

26. C. Lian, Y. Zhuge, "Optimum mix design of enhanced permeable concrete-an experimental investigation." Construction and Building Materials 24.12: 2664-2671, 2010.

27. Concrete, Pervious."ACI 522R-06." American Concrete Institute, Farmington Hills, Mich, 2006.

28. ASTM, C. "192. 2004. Standard Practice for Making and Curing Concrete Test Specimens in the Laboratory." Annual book of ASTM Standards 4, 2006.

29. B. F. Ferguson, "Porous Pavements Integrative Studies in Water Management and Land Development". 2005.

30. N. Neithalath, M. S. Sumanasooriya, "Characterizing pore volume, sizes, and connectivity in pervious concretes for permeability prediction", Materials characterization, 61.8: 802-813, 2010.

31. M. Chopra, S. Kakuturu, "Effect of rejuvenation methods on the infiltration rates of pervious concrete pavements." Journal of Hydrologic Engineering, 15.6: 426-433, 2009.

32. Cahill Associates, "Pervious pavement opration and maintenance protocol, 2011.

33. R. J.Winston, AM. Al-Rbaei, "Maintenance measures for preservation and recovery of permeable pavement surface infiltration rate-The effects of street sweeping, vacuum cleaning, high pressure washing, and milling." Journal of environmental management, 169: 132-144, 2016. 


\section{LiST OF FigURES}

Figure 1. Pervious concrete specimens

Rysunek 1. Próbki betonu jamistego

Figure 2. Sedimentation material

Rysunek 2. Materiał sedymentacyjny

Figure 3. Clogging test

Rysunek 3. Badanie kolmatacji

Figure 4. Clogged specimen a) Clay, b) Sand and c) Clayey silt sand

Rysunek 4. Zatkana próbka a) Glina, b) Piasek i c) Piasek gliniasto-mulisty

Figure 5. Pressure washing test

Rysunek 5. Test mycia ciśnieniowego

Figure 6. Vacuuming test

Rysunek 6. Test czyszczenia próżniowego

Figure 7. a) Clay sedimentation b) Sand sedimentation and c) Clayey silty sand sedimentation

Rysunek 7. a) Sedymentacja gliny, b) Sedymentacja piasku i c) Sedymentacja piasku gliniasto-mulistego

Figure 8. Sand clog cleaning by a) Pressure washing b) Vacuuming and c) Combined method

Rysunek 8. Oczyszczanie zalegającego piasku za pomocą a) Czyszczenia ciśnieniowego, b) Czyszczenia próżniowego i c) Metody łączonej

Figure 9. Clayey silty sand clog cleaning by a) Pressure washing b) Vacuuming and c) Combined method

Rysunek 9. Czyszczenie zalegającego piasku gliniasto-mulistego za pomocą a) Czyszczenia ciśnieniowego,

b) Czyszczenia próżniowego i c) Metody łączonej 


\section{EKSPERYMENTALNE BADANIE DOTYCZACE USUWANIA BETONU JAMISTEGO NA DRODZE SEDYMENTACJI}

Slowa kluczowe: Beton jamisty, kolmatacja, przepuszczalność, sedymentacja, woda burzowa

\section{STRESZCZENIE:}

Urbanizacja stwarza liczne problemy, takie jak erozja, gwałtowne powodzie, zanieczyszczenie rzek oraz efekt wyspy ciepła. Beton jamisty jest przyjaznym dla środowiska materiałem nawierzchniowym, który częściowo ogranicza wyżej wspomniane problemy, a także służy zachowaniu środowiska naturalnego, zmniejszając spływ wody burzowej, zanieczyszczenia oraz miejskie ciepło. Beton jamisty jest podobny do zwykłego betonu, z wyjątkiem dodatku drobnego kruszywa, które tworzy połączone ze sobą puste przestrzenie umożliwiające przepływ wody przez betonową matrycę. Pustki od $15 \%$ do $35 \%$ całkowitej objętości betonu jamistego są utrzymywane za pomocą gruboziarnistego kruszywa o ciągłej krzywej przesiewu i gęstego cementu, który zapobiega oddzielaniu się pasty od kruszywa. Wydajność hydrauliczna betonu jamistego dla odprowadzenia wody burzowej zależy od szybkości odkładania się osadu w odniesieniu do okresu czasu. Kolmatacja betonu jamistego stanowi istotny potencjalny problem w zakresie użytkowalności, który jest uważany za jedno z podstawowych ograniczeń w systemach betonu jamistego. Kolmatacja odnosi się do zmniejszenia przepuszczalności porowatego ośrodka ze względu na proces fizyczny, chemiczny i biologiczny. Głównymi źródłami kolmatacji są zawieszone cząstki z powierzchniowych wód spływających, a także organiczne i nieorganiczne cząstki pochodzące z ruchu drogowego i miejscowej roślinności lub pyłu wydmuchiwanego na jezdni.

Niniejsze badanie koncentruje się na wydajności hydraulicznej systemu betonu jamistego poprzez wywoływanie kolmatacji przy użyciu różnych materiałów sedymentacyjnych i ocenie zdolności infiltracji betonu jamistego. Prace eksperymentalne przeprowadzono, aby zrozumieć przydatność metod renowacyjnych w przywracaniu wydajności hydraulicznej betonu jamistego. Celem tego badania jest ocena efektu kolmatacji betonu jamistego w oparciu o trzy różne materiały sedymentacyjne, trzy różne stopnie uziarnienia kruszywa i trzy metody renowacji. Służy to określeniu zmniejszenia przepuszczalności po kolmatacji i resztkowej przepuszczalności po oczyszczeniu próbek betonu jamistego.

Mieszanki betonu jamistego przygotowano zgodnie z ACI 522R-2006 przy użyciu zwykłego cementu portlandzkiego, woda oraz wielkości gruboziarnistego kruszywa zostały przyjęte jako przechodzące przez $16 \mathrm{~mm}$ i zatrzymane na 12,5 mm sicie, przechodzące przez $12,5 \mathrm{~mm}$ i zatrzymane na $9,5 \mathrm{~mm}$, a także przechodzące przez $9,5 \mathrm{~mm}$ i zatrzymane na $4,75 \mathrm{~mm}$ sicie. Wielkości kruszywa zostały wybrane w celu ułatwienia nieciągłego uziarnienia i utrzymania struktury otwartych porów. Mieszanki betonu jamistego były dozowane przy użyciu wyżej wspomnianych kruszyw w stosunku wody do cementu wynoszącym 0,33 oraz stosunku kruszywa do cementu wynoszącym 4 dla całej mieszanki. Dwadzieścia siedem próbek o średnicy $100 \mathrm{~mm}$ i wysokości $200 \mathrm{~mm}$ w każdej grupie odlano i utwardzono w wodzie w celu przeprowadzenia testu kolmatacji.

W tym badaniu zastosowano trzy typy materiałów zapychających, takie jak glina, piasek oraz piasek gliniasto-mulisty. Analiza wielkości cząstek została przeprowadzona dla materiałów sedymentacyjnych, aby w istotny sposób wpłynąć na infiltrację. Do przeprowadzenia badania kolmatacji wykorzystano piasek jako gruboziarnisty materiał osadu o wielkości przechodzącej przez $2 \mathrm{~mm}$ sito i zatrzymanej na sicie o gęstości 75 mikronów, drobny osad przechodzący przez sito o gęstości 75 mikronów wraz z 25\% gliny oraz połączeniem gliniasto-mulistego piasku o $60 \%$ gruboziarnistych osadów i 
$40 \%$ drobnych osadów. Glina, piasek i połączenie gliniasto-mulistego piasku o objętości 40 g każdy zmieszano z 3 litrami wody, a następnie pozwolono na kolmatację trzech różnych mieszanek próbek betonu jamistego.

Kolmatację można ocenić poprzez pomiar przepuszczalności próbek cylindrycznych w oparciu o zasadę przepuszczalnościomierza o zmiennym naporze w podejściu jednowymiarowego przepływu. Współczynnik przepuszczalności został obliczony na podstawie prawa Darcy’ego. Cykl kolmatacji składa się zarówno z kolmatacji w pierwszym etapie, jak i czyszczenia w drugim etapie. W każdym cyklu badania, materiał zapychający zostaje równomiernie zmieszany $\mathrm{z}$ wodą i wylany na wierzch próbki testowej, następnie mierzy się przepuszczalność, pozwalając wodzie przepływać przez próbkę wraz z zawieszonym materiałem zapychającym. Woda została całkowicie opróżniona i wybrano dowolną metodę oczyszczania w celu wyczyszczenia zatkanych próbek. W tym badaniu przyjęto trzy różne metody czyszczenia, takie jak czyszczenie ciśnieniowe, czyszczenie próżniowe i metoda łączona. Po oczyszczeniu, ponownie przeprowadzono test przepuszczalności, umożliwiając przepływ czystej wody przez oczyszczoną próbkę i odnotowano przepuszczalność.

Stwierdzono, że zatkanie gliną powoduje znacznie mniejszy spadek przepuszczalności po dziesięciu cyklach kolmatacji, a zatem stosowanie jakichkolwiek metod czyszczenia nie jest wymagane. W tym teście zachowano ponad 92\% początkowej przepuszczalności po 10 cyklach obciążenia sedymentacyjnego. Zmniejszenie przepuszczalności jest spowodowane bardzo drobnymi cząstkami wnikającymi w pory oraz innymi cząstkami przenoszonymi przez wodę.

Materiały sedymentacji piasku wykazują znaczną redukcję przepuszczalności we wszystkich trzech mieszankach. Resztkowa przepuszczalność zmienia się bezpośrednio w stosunku do wielkości kruszywa i porowatości próbki betonu jamistego. Średnią z ponad $50 \%$ przepuszczalności z trzech mieszanek utracono w przypadku sedymentacji piasku, w której większość cząstek piasku o mniejszej kohezji została zatrzymana na powierzchni lub w porach próbki. W tym badaniu sedymentacji, próbki betonu jamistego o niskiej porowatości działają jak warstwa filtrująca w celu usunięcia większych cząstek stałych $\mathrm{w}$ ładunku sedymentacyjnym i powodują zmniejszenie przepuszczalności. Na efekt sedymentacji i zmniejszenie przepuszczalności betonu jamistego wpłynęła porowatość, rozkład wielkości porów i materiał zapychający.

Kiedy gliniasto-mulisty piasek jest stosowany jako materiał sedymentacyjny podobny do piasku, występuje wówczas znacząca zmiana przepuszczalności dla wszystkich trzech mieszanek. Zaobserwowano, że cząstki gliny zostały przepłukane przez płynącą wodę, a cząstki piasku zostały zatrzymane na górnej powierzchni próbki. W procesie sedymentacji gliniasto-mulistego piasku, zmieszany materiał o szerokim zakresie rozkładu wielkości cząstek powoduje kolmatację porów. Próbki o większym rozmiarze kruszywa wykazują dużą objętość porów, co prowadzi do zwiększenia nośności sedymentacyjnej, a zatem procent pozostający w początkowej przepuszczalności jest zwiększony.

Wybór metody czyszczenia zależy od porowatości betonu jamistego i właściwości materiałów sedymentacyjnych. Metoda czyszczenia ciśnieniowego i próżniowego wykazuje w przybliżeniu taką samą skuteczność czyszczenia, a metoda łączona wykazuje większy procent pozostającej początkowej przepuszczalności po 10 cyklach kolmatacji piasku oraz procesu czyszczenia. Zarówno metoda czyszczenia ciśnieniowego jak i próżniowego ujawnia stałą wydajność w czyszczeniu sedymentacji piasku, natomiast znacznie różni się w przypadku czyszczenia sedymentacji piasku gliniasto-mulistego. W oparciu o wyniki eksperymentalnych badań, łączona metoda czyszczenia pod ciśnieniem oraz czyszczenia próżniowego jest uważana za najlepszą metodę odzyskiwania przepuszczalności sedymentacji piasku oraz gliniasto-mulistego piasku. Wyniki tego badania wskazują, że metody czyszczenia sedymentacyjnego mogą znacznie przywrócić wydajność nawierzchni z betonu jamistego dla lepszego zarządzania wodą burzową. 